SSCM T

Journal of Sustainable Construction

Materials and Technologies

J Sustain. Construct. Mater. Technol. 5(1) (2020) 399-406
Journal of Sustainable Construction Materials

and Technologies

www.eds.yildiz.edu.tr/jscmt

\title{
Starch-Based Bioplastic Materials for Packaging Industry
}

\author{
Murat Ates ${ }^{1, *}$, Pinar $\mathrm{Kuz}^{1}$ \\ ${ }^{1}$ Atespolymer Research group, Physical Chemistry Division, Department of Chemistry, Faculty of Arts and Sciences, Namik \\ Kemal University, Degirmenalti Campus, 59030, Tekirdag, Turkey
}

Manuscript Received November 16, 2019; Accepted February 24, 2020

\begin{abstract}
In this study, we performed the production of bioplastic from corn starch by condensation polymerization. We used a natural intensifier such as glycerin to make the corn starch into a bioplastic material. Bioplastic and its nanocomposites via carbon fiber microelectrode (CFME), $\mathrm{TiO}_{2}$ and nanoclay were synthesized to study its application in package industry. FTIRATR, TGA-DTA, SEM-EDX and mechanical analysis were taken to characterize the bioplastic based nanocomposites. We used different amounts of addition of CFME $(0.2 \%, 0.5 \%$ and $1 \%), \mathrm{TiO}_{2}(1 \%, 3 \%$ and $5 \%)$ and nanoclay $(1 \%, 3 \%$ and $5 \%)$ to obtain the optimum condition for the bioplastic material. We obtained proper results for bioplastic/CFME nanocomposite addition of $1 \%$, bioplastic / $\mathrm{TiO}_{2}$ and bioplastic / nanoclay nanocomposites addition of $5 \%$ in the composite material. Based on the literature that can be used in packaging industry without harming the environment, this is our main objective.
\end{abstract}

Keywords: Polymer; biopolymer; bioplastic; biodegradable materials; packaging industry; mechanical properties

\section{Introduction}

Biopolymers are polymers produced by living organisms. Examples are cellulose, starch, chitin, proteins, peptides, DNA and RNA biopolymers. These biopolymers are composed of monomers called sugars, amino acids and nucleotides, respectively [1]. Plastics are known as very robust materials. They are lighter and cheaper than many other materials, except that they are processed in different shapes. But the materials we have heard as bioplastics in recent years are innovative plastics made from renewable raw materials. Corn starch bioplastics are used in many areas such as textile papers, cartoon glue etc [2]. Starch is preferred in bioplastic production due to its low price [3]. However, it has some disadvantages such as low mechanical properties and high humidity absorption etc. In our article we focused on developing new type of composite materials to solve these problems [4]. To increase low mechanical properties of bioplastics, Titanium dioxide $\left(\mathrm{TiO}_{2}\right)$, carbon fiber microelectrode (CFME) or nanoclay are added to polymer matrix [5-9]. OH groups in cellulose helps to do hydrogen bonds in bioplastics, so its mechanical properties will be improved in composite material. CFMEs are used as an additive material in nanocomposites and they are friendly environment materials $[10,11]$. In literature, graphene oxide (GO) and poly(vinyl alcohol) (PVA) nanocomposite were designed to have high water absorbing capacity along with improvement in tensile strength and thermal stability [12]. It is indicated that there is a great improvement in tensile strength and swelling resistance of nanocomposite materials.

In addition to starch, polymers such as cellulose, lignin, nylon, polyethylene, polypropylene, polylactic acid and PHA have also begun to be biologically synthesized for bioplastic production. Biopolymers are obtained from natural starch, which are economic and biodegradable materials [13, 14]. They can be used in package industry due to these advantages. Mlalila et al [15] have presented about food packaging industry which concentrates on biodegradable packaging materials and designing of antimicrobial packaging for long-term selflife. There are many studies in the world [16-18].

\footnotetext{
* Corresponding author:

E-mail address: mates@nku.edu.tr(Ateş, M.)
} 


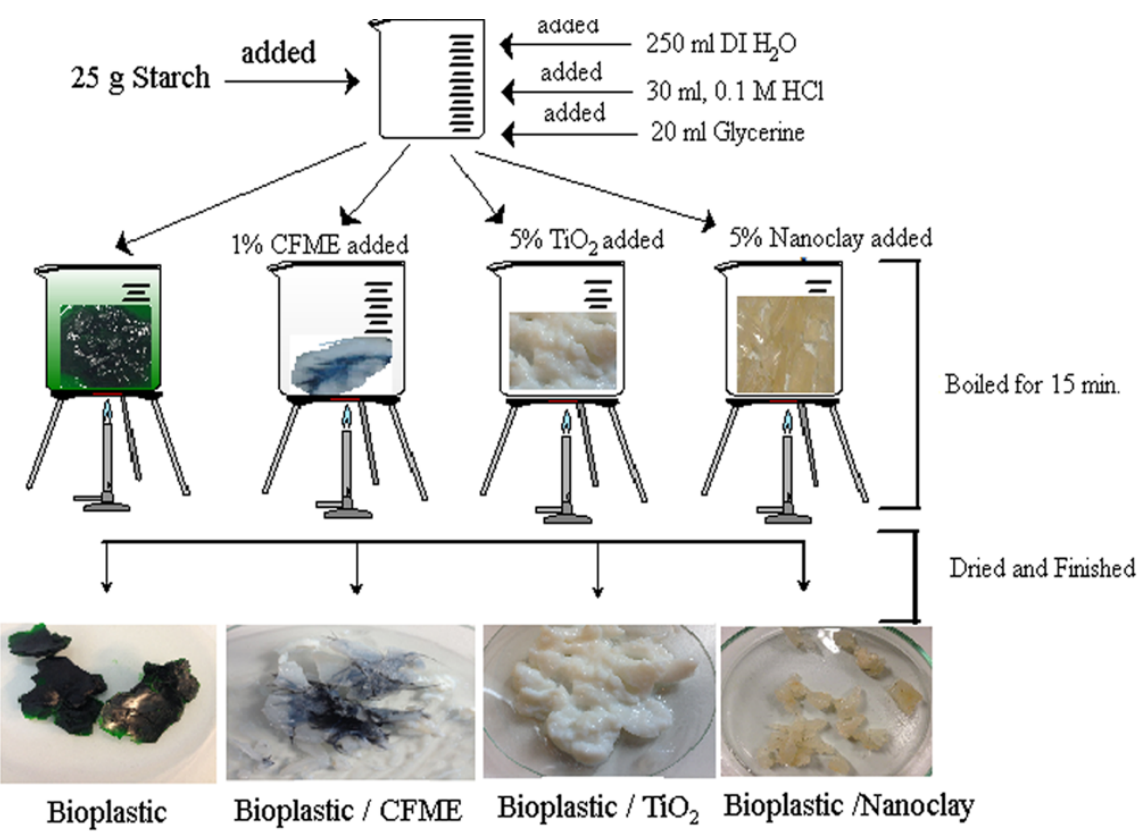

Figure 1. Synthesis procedure of bioplastic, bioplastic/CFME, bioplastic/ $\mathrm{TiO}_{2}$ and bioplastic/Nanoclay nanocomposites.

As a result, we chose the best conditions of their different amounts of additives such as for CFME as $1 \%$ addition, for nanoclay as $5 \%$ addition and for $\mathrm{TiO}_{2}$ as $5 \%$ addition. All bioplastic based nanocomposites were prepared in these amounts and characterized in this optimum conditions. The goal of this study is to define a more proper bioplastic based materials including some additives, such as CFME, nanoclay, or $\mathrm{TiO}_{2}$. These bioplastic nanocomposite has some good spectroscopic, morphological and mechanical properties to use as a packaging material. In food industry, it's beneficial to use renewable organic materials due to their antibacterial, eco-friendly, cheaper, and easily degradation of package dispose. The main aim of the article is the synthesis of starch-based bioplastic materials including CFME, $\mathrm{TiO}_{2}$, and nanoclay for packaging industry. There is no systematic correlation related to these materials in literature.

\section{Experimental Study}

\subsection{Materials}

Corn starch (commercially provided from market), $\mathrm{HCl}$ (Sigma-Aldrich, 37\%), glicerine (Bikar), petri vessel and cover vessel (Isolab), $\mathrm{TiO}_{2}$ (nanopowder, $21 \mathrm{~nm}$ particle size $\geq 99.5 \%$ trace metals basis, Sigma Aldrich), Carbon fiber (SCL Sigrafil C 320 B, high resistance, high elastic modules and high electric conductivity, SGL Carbon Group. diameter: $\sim 7 \mu \mathrm{m}$ ), nanoclay as a type of Montmoriilonite (surface modified, Sigma Aldrich), Food additive dye (KRK company) arec used in different steps of the experiments.

\subsection{Instrumentations}

Deionized water device (purelab Option-Q, ELGA, DV25, Elga LLC, Illinois, USA), hot plate (Heidolph, MR Hel-Std, Germany), SEM-EDX (FEI, QUANTA FEG250), oven (DRY-Line VWR, VWR International Ltd. Leicestershire, England), TGA-DTA (TGA-DTA, EXSTAR 6300), Mechanical Tests (Baz machine, Turkey), FTIR-ATR (Perkin Elmer Spectrum One B) were used in different steps of the experiments.

\subsection{Synthesis of Bioplastic Materials}

Firstly, $25 \mathrm{~g}$ starch was taken for a beaker and added $250 \mathrm{ml}$ DI water, $30 \mathrm{ml}, 0.1 \mathrm{M} \mathrm{HCl}$ and $20 \mathrm{ml}$ glycerin. It was boiled for 15 minute on hot plate. Later, it was poured to petri plate and the samples were dried at $30^{\circ} \mathrm{C}$ in an oven. Secondly, different percent amount of $\mathrm{TiO}_{2}, \mathrm{CFME}$ and nanoclay were added to bioplastic to form nanocomposite materials as bioplastic, bioplastic/CFME, bioplastic/ $\mathrm{TiO}_{2}$ and bioplastic/nanoclay nanocomposites (Figure 1).

\subsection{Preparation of composite materials}


The bioplastic material and bioplastic $/ \mathrm{TiO}_{2}$ nanocomposites at $1 \%, 3 \%$ and $5 \% \quad \mathrm{TiO}_{2}$ addition, bioplastic/CFME nanocomposite at $0.2 \%, 0.5 \%$ and $1 \%$ CFME addition, and bioplastic/nanoclay nanocomposite at $1 \%, 3 \%$ and $5 \%$ nanoclay addition were synthesized in a chemical way as shown in Figure 2.

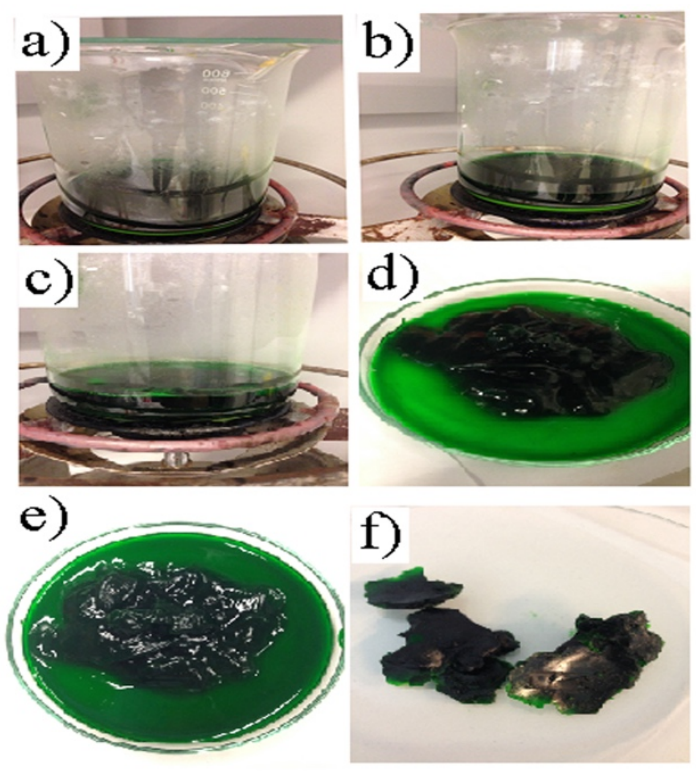

Figure 2. Photographs of bioplastic synthesis procedure. a) All samples were dispersed in DI water and then boils. b) Photographs during boiling process. c) After $15 \mathrm{~min}$. of boiling process, samples were taken into petri plate. d) Waiting duration for one day in petri plate. e) Samples with duration for 5 days. f) The last version of used in experiments.

\section{Results \& Discussion}

\subsection{FTIR-ATR Analysis}

FTIR-ATR analysis of bioplastic, bioplastic/CFME, bioplastic/nanoclay and bioplastic/TiO ${ }_{2}$ nanocomposites were shown in Figure 3. The broad peaks at 3273, 3290, 3292 and $3271 \mathrm{~cm}^{-1}$ belong to O-H stretching for bioplastic, bioplastic/CFME, bioplastic/nanoclay and bioplastic/ $\mathrm{TiO}_{2}$ nanocomposites, respectively. The peak at $1416 \mathrm{~cm}^{-1}$ and $1151 \mathrm{~cm}^{-1}$ refer to $\mathrm{C}-\mathrm{C}$ stretching and C-O stretching, respectively [19, 20]. The peak at $2923 \mathrm{~cm}^{-1}$ indicates absorption band of $\mathrm{C}-\mathrm{H}$ stretching. Moreover, the peak at $1651 \mathrm{~cm}^{-1}$ corresponds to $\mathrm{C}=\mathrm{C}$ bonds of the nanocomposite materials corresponds to the $\mathrm{sp}^{2}$ character [21]. The starch based bioplastic and nanocomposites including 1\% CFME, 5\% nanoclay and 5\% $\mathrm{TiO}_{2}$ were successfully synthesized which are shown in FTIR-ATR analysis.

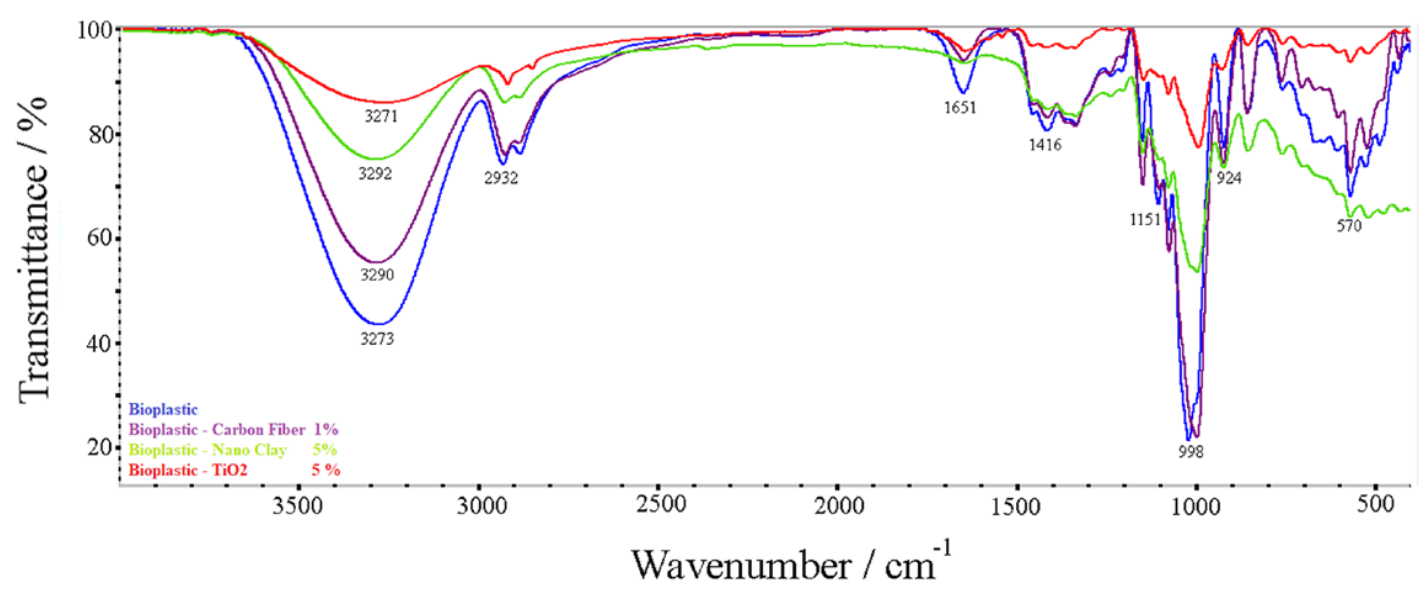

Figure 3. FTIR-ATR spectrums of bioplastic bioplastic/CFME for CFME as 1\% addition, bioplastic/nanoclay for nanoclay as $5 \%$ addition and bioplastic/ $/ \mathrm{TiO}_{2}$ nanocomposites for $\mathrm{TiO}_{2}$ as $5 \%$ addition. 


\subsection{TGA-DTA Analysis}

TGA-DTA measurements were taken at heating rate of $25^{\circ} \mathrm{C} / \mathrm{min}$ from room temperature to $1000{ }^{\circ} \mathrm{C}$. The results show that there is a fast decrease after $300{ }^{\circ} \mathrm{C}$ for bioplastic materials. We took pure bioplastic material as a reference substance. It shows only $3 \%$ material lost at $101.1{ }^{\circ} \mathrm{C}$. This material lost occurs $82.9 \%$ at $256.8{ }^{\circ} \mathrm{C}$ and $36 \%$ at $351.3{ }^{\circ} \mathrm{C}$. The bioplastic degrades $1.1 \%$ at $546.7{ }^{\circ} \mathrm{C}$. Its nearly consumes all material $0.6 \%$ at $596.5^{\circ} \mathrm{C}$. The reason of this decrease reports from moisture of $\mathrm{H}_{2} \mathrm{O}$ in literature [22]. DTA measurements show that the reactions are endothermic process [23].
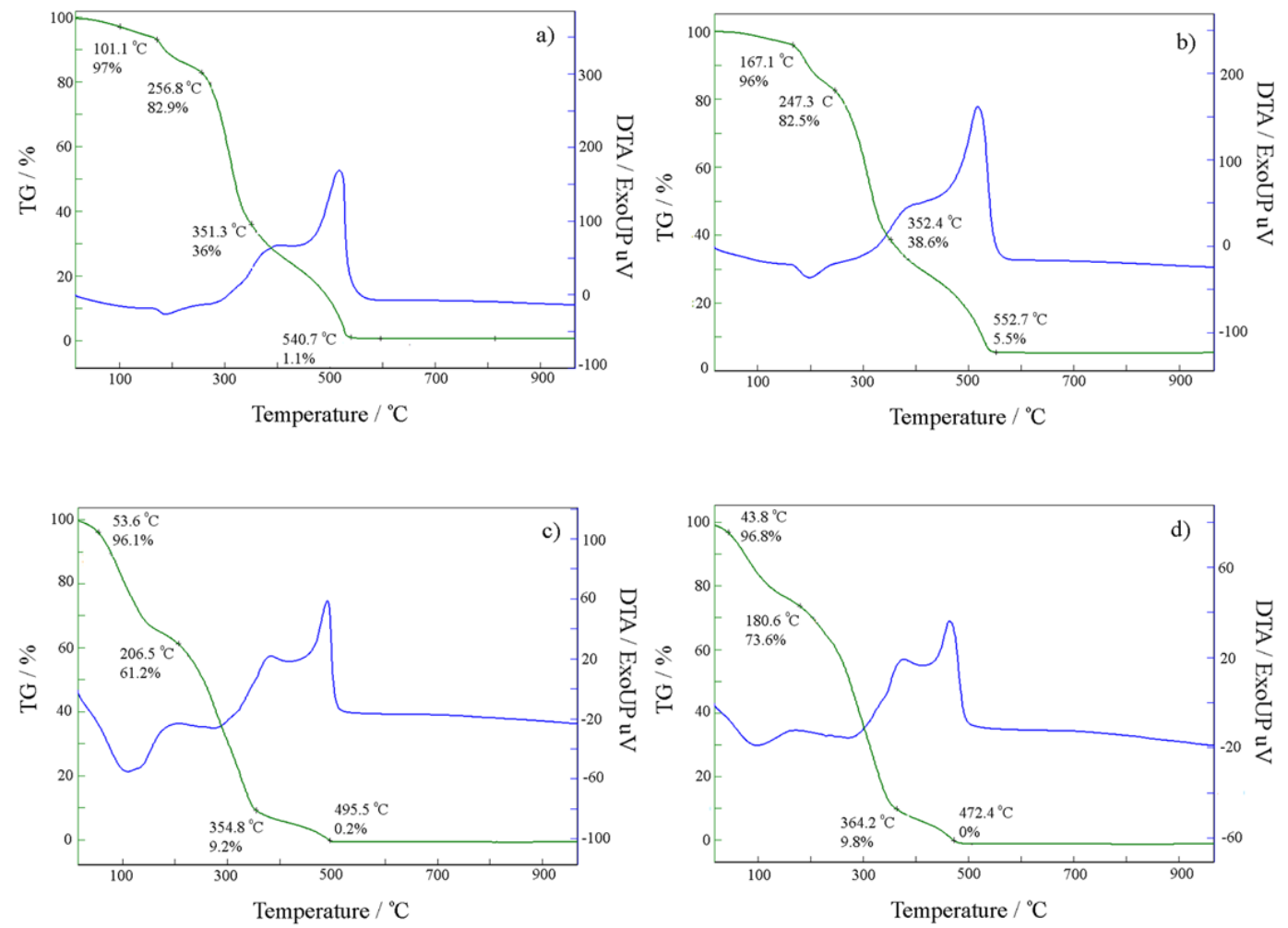

Figure 4. TGA-DTA analysis of bioplastic, bioplastic/CFME for CFME as $1 \%$ addition, bioplastic/nanoclay for nanoclay as $5 \%$ addition and bioplastic/ $/ \mathrm{TiO}_{2}$ nanocomposites for $\mathrm{TiO}_{2}$ as $5 \%$ addition.

\subsection{SEM-EDX analysis}

SEM images of bioplastic, bioplastic/CFME, bioplastic/nanoclay and bioplastic/ $\mathrm{TiO}_{2}$ nanocomposites were given in Figure 5. The SEM images of bioplastic material shows a wavy and homogeneous structure (Fig.5a). This wavy images may come from corn starch and these granulles may not melt on the surface material [24]. According to mechanical test analysis, we obtained a rigid structure for bioplastic/ $\mathrm{TiO}_{2}$ or $\mathrm{CFME}$ or nanoclay nanocomposites than bioplastic materials. CFME addition in nanocomposite structure was really differentiate than the other images (Fig. 5b). However, there is no significant change between bioplastic/nanoclay (Fig.5c) and bioplastic/ $/ \mathrm{TiO}_{2}$ images (Fig.5d) due to the structure of additive materials. 

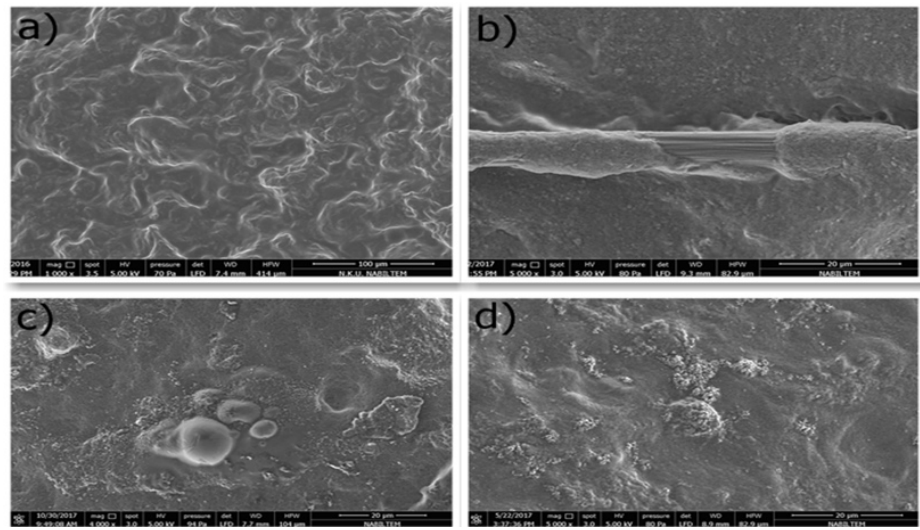

Figure 5. SEM images of a) Bioplastic, b) Bioplastic/CFME for CFME as 1\% addition, c) Bioplastic/Nanoclay for nanoclay as $5 \%$ addition and d) Bioplastic/ $\mathrm{TiO}_{2}$ nanocomposites for $\mathrm{TiO}_{2}$ as $5 \%$ addition.

\subsection{Solubility tests}

Bioplastic nanocomposites obtained from corn starch (Bioplastic, Bioplastic/CFME for CFME as 1\% addition, Bioplastic/Nanoclay for nanoclay as $5 \%$ addition and Bioplastic/ $\mathrm{TiO}_{2}$ nanocomposites for $\mathrm{TiO}_{2}$ as $5 \%$ addition) were dissolved in different solvents to test solubility as given in Fig.6. Materials can be solved in different solution color in different solvents such as sulphuric acid, hydrochloric acid, sodium hydroxide, acetonitrile and ethyl alcohol. For example, solution color was obtained dark and light yellow for $\mathrm{H}_{2} \mathrm{SO}_{4}, \mathrm{HCl}$ and $\mathrm{NaOH}$ solvents. It was obtained dark and light green color for acetonitrile and ethyl alcohol. As a result, these solubility tests support the usage as food package industry for these biodegradable materials.
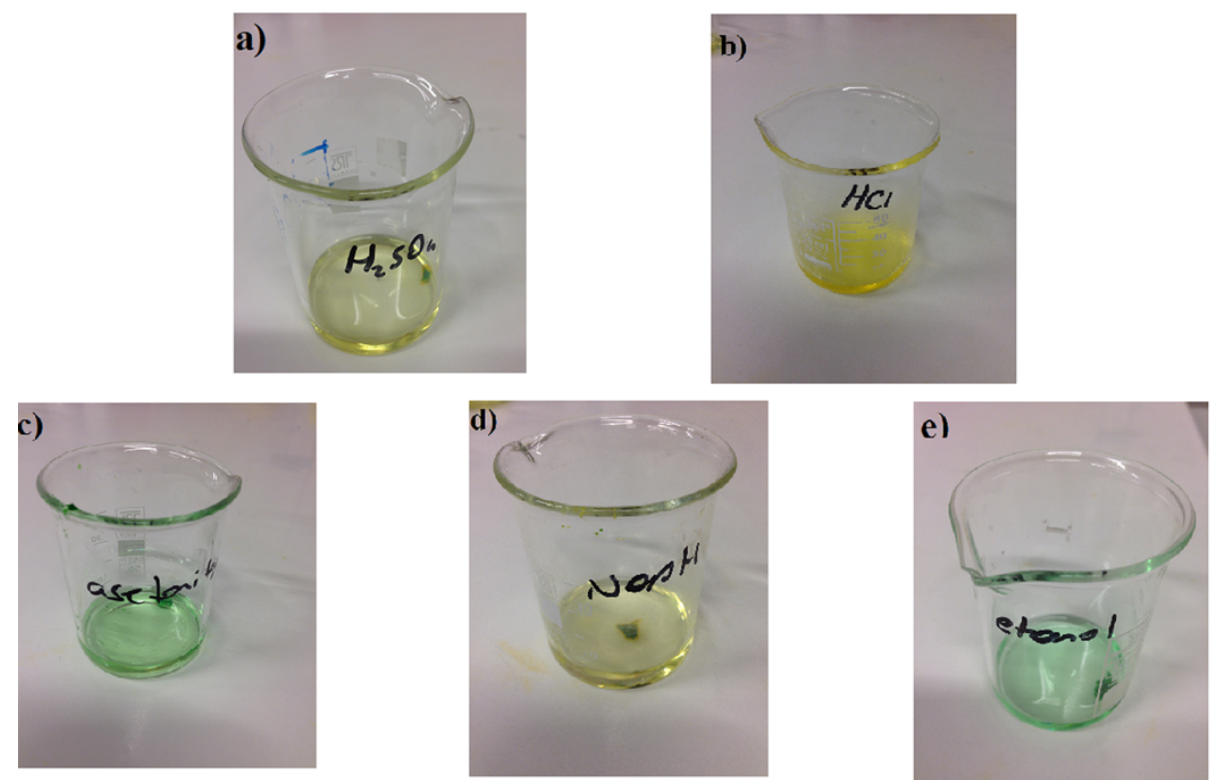

Figure 6. Solubility photography of biodegradable materials in a) $95-97 \% \mathrm{H}_{2} \mathrm{SO}_{4}$, b) $37 \% \mathrm{HCl}$, c) $99.9 \%$ acetonitrile, d) $99 \%$ $\mathrm{NaOH}$ and e) $99.8 \%$ ethyl alcohol.

\subsection{Mechanical properties}

The addition of inorganic fillers such as Montmorillonite (MMT) nanoclay, $\mathrm{TiO}_{2}$, or CFME into a bioplastic material could increase its mechanical properties. In literature, Trivino et al [25]. have studied the MMT nanoclays which improves the biopolymers rheological and mechanical properties due to a high exfoliation of the nanoclay. If we use bioplastic nanocomposites in cement as building materials, it prevents cement reactions and hydration. Bending resistance of these nanocomposites decrease compared to bending resistance of reference material. It also has breakage of the material so bending resistance, pressure resistance 
and breakage forces were clearly decreased in the mechanical test results as shown in Figure $7 \&$ Table 1 . These materials may be used in food package materials in industry.
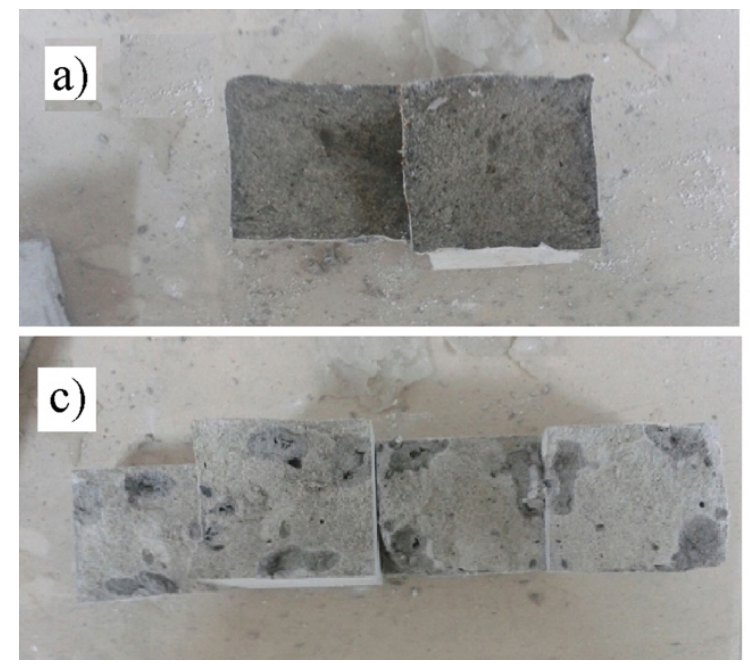
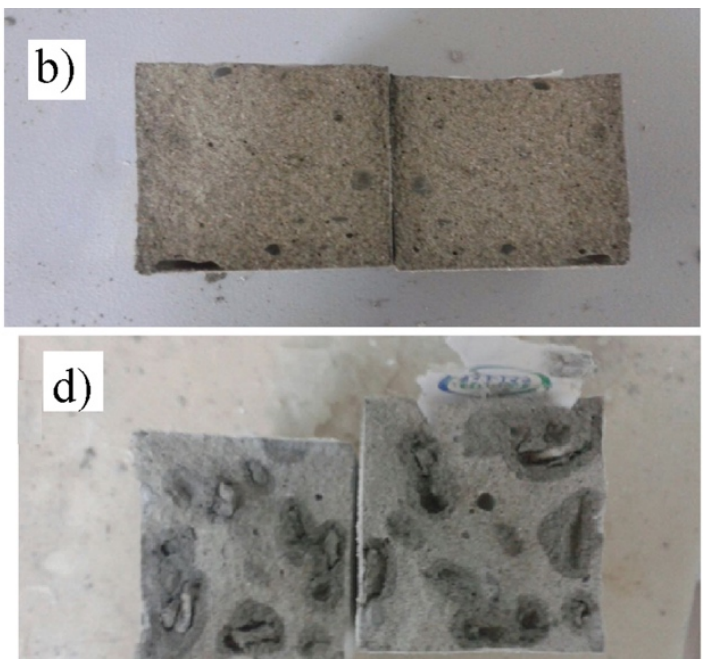

Figure 7. The photography of concrete block composites, a) bioplastic, b) bioplastic $/ \mathrm{TiO}_{2}$ for $\mathrm{TiO}_{2}$ as $5 \%$ addition c) bioplastic/nanoclay for nanoclay as 5\% addition and d) bioplastic/CFME materials for CFME as $1 \%$ addition.

Table 1. Mechanical test results of bioplastic, bioplastic/ $\mathrm{TiO}_{2}$, bioplastic/nanoclay, bioplastic/CFME and bioplastic reference materials. W: wide, L: length, So: Area, h: height. Bioplastic reference blocks were taken volume of $256 \mathrm{~cm}^{3}$. CFME additive was added $1 \%$ amount but nanoclay and $\mathrm{TiO}_{2}$ were added $5 \%$ amount in nanocomposite material.

\begin{tabular}{|c|c|c|c|c|c|c|c|c|c|}
\hline \multirow{2}{*}{ Samples } & \multirow{2}{*}{$\begin{array}{l}\text { Epx. } \\
\text { name }\end{array}$} & \multicolumn{4}{|c|}{ Physical properties } & \multirow{2}{*}{$\begin{array}{l}\text { Bending } \\
\text { resistance } \\
\mathrm{N} / \mathrm{mm}^{2}\end{array}$} & \multirow{2}{*}{$\begin{array}{l}\text { Pressure } \\
\text { resistance } \\
\mathrm{N} / \mathrm{mm}^{2}\end{array}$} & \multirow{2}{*}{$\begin{array}{l}\text { Breaking } \\
\text { force } \\
\mathrm{N}\end{array}$} & \multirow{2}{*}{$\begin{array}{c}\text { Ave. } \\
\text { Velocity } \\
\mathrm{mm} / \mathrm{s}\end{array}$} \\
\hline & & $\begin{array}{c}\mathrm{W} \\
\mathrm{mm}\end{array}$ & $\begin{array}{c}\mathrm{L} \\
\mathrm{mm}\end{array}$ & $\begin{array}{l}\text { So } \\
\mathrm{mm}^{2}\end{array}$ & $\begin{array}{l}\mathrm{h} \\
\mathrm{mm}\end{array}$ & & & & \\
\hline \multirow[b]{2}{*}{ Bioplastic } & Bending & 40 & 160 & 6400 & 40 & 1.77 & $\begin{array}{ll}--- \\
\end{array}$ & $\begin{array}{ll}--- \\
\end{array}$ & $\begin{array}{ll}--- \\
\end{array}$ \\
\hline & Pressure & 40 & 40 & 1600 & 40 & $\begin{array}{ll}-- \\
\end{array}$ & 3.63 & ---- & ---- \\
\hline \multirow[b]{2}{*}{$\begin{array}{c}\text { Bioplastic / } \\
\mathrm{TiO}_{2}\end{array}$} & Bending & 40 & 160 & 6400 & 40 & 2.16 & $\begin{array}{ll}--- \\
\end{array}$ & $\begin{array}{ll}--- \\
\end{array}$ & $\begin{array}{ll}--- \\
\end{array}$ \\
\hline & Pressure & 40 & 40 & 1600 & 40 & $\begin{array}{l}--- \\
\end{array}$ & 8.39 & $\begin{array}{ll}--- \\
\end{array}$ & $\begin{array}{ll}--- \\
\end{array}$ \\
\hline \multirow[b]{2}{*}{$\begin{array}{c}\text { Bioplastic / } \\
\text { nanoclay }\end{array}$} & Bending & 40 & 160 & 6400 & 40 & 2.20 & ---- & 940 & 16.94 \\
\hline & Pressure & 40 & 40 & 1600 & 40 & ---- & 6.68 & 10691 & 286.5 \\
\hline \multirow[b]{2}{*}{$\begin{array}{c}\text { Bioplastic / } \\
\text { CFME }\end{array}$} & Bending & 40 & 160 & 6400 & 40 & 2.45 & $\begin{array}{ll}--- \\
\end{array}$ & 1047 & 17.97 \\
\hline & Pressure & 40 & 40 & 1600 & 40 & ---- & 7.49 & 11973 & 366.07 \\
\hline \multirow[b]{2}{*}{$\begin{array}{l}\text { Bioplastic } \\
\text { Reference }\end{array}$} & Bending & 40 & 160 & 6400 & 40 & 3.77 & ---- & $\begin{array}{ll}---- \\
\end{array}$ & ---- \\
\hline & Pressure & 40 & 40 & 1600 & 40 & $\begin{array}{l}--- \\
\end{array}$ & 10.20 & 16314 & 438.68 \\
\hline
\end{tabular}

\section{Conclusion}

High mechanical properties materials, non-toxicity, eco-friendly and proper biodegradability are greatly demand for food packaging technology. We designed corn-starch bioplastic materials, which has added via CFME, $\mathrm{TiO}_{2}$, and nanoclay to obtain high mechanically strong and biodegradable materials. These materials were characterized with FTIR-ATR, SEM-EDX, TGA-DTA, solubility and mechanical tests. As a result, bioplastic/CFME and materials have high breaking force $(11973 \mathrm{~N})$ and average velocity $(366.07 \mathrm{~mm} / \mathrm{s})$. Bioplastic/CFME or $\mathrm{TiO}_{2}$ or nanoclay nanocomposite may be used in food package industry. 


\section{Acknowledgement}

Authors would like to thank expert Muhammet Aydın (Tekirdag Namik Kemal University, NABILTEM, Tekirdag, Turkey) for recording SEM-EDX, FTIR-ATR, TGA-DTA and Serkan Yavuz for mechanical test measurements.

\section{Author contributions}

The manuscript was written through the contributions of all authors. All authors have given approval to the final version of the manuscript.

\section{Conflict of interest}

The authors declared none. This is an original work and has not been published before or submitted for publication to another journal.

\section{References}

1. Li, XR, Garamus VM, Li N, Gong YB, Zhe Z, Tian ZF, Zou AH (2018) Preparation and characterization of a pHresponsive mesoporous silica nanoparticle dual-modified with biopolymers. Colloids and Surfaces APhysicochemical and Engineering aspects, 548:61-69

2. Rouger J, Mutje P (1984) Correlation between the cellulose fibers beating and the fixation of a soluble cationic polymer. British Polym J 16:83-86

3. Mose BR, Maranga SM (2011) A review on starch based nanocomposites for bioplastic materials. J Mat Sci Eng 1:239-245

4. Wittaya T (2009) Microcomposites of rice starch film rein forced with microcrystalline cellulose from palm pressed fiber. Int Food Res J 16:493-500

5. Dufresne A, Dupeyre D, Vignon MR (2000) Cellulose Microfibrils from Potato tuber cells:processing and characterization of starch-cellulose microfibril composites. J Appl Polym Sci 76:2080-2092

6. John MJ, Thomas S (2008) Biofibres and biocomposites. Carbohydrate Polymers 71:343-364

7. Belhassen R, Boufi S, Vilaseca F, Lopez JP, Mendez JA, Franco E, Pelach MA, Mutje P (2009) Biocomposites based on Alfa fibers and starch-based biopolymer. Polym Adv Technol 20:1068-1075

8. Alvarez VA, Kenny JM, Vazquez A (2004) Creep behavior of biocomposites based on sisal fiber reinforced cellulose derivatives / starch blends. Polym Comp 25:280-288

9. Alvarez VA, Ruseckaite RA, Vazquez A (2006) Degradation of sisal fibre/Mater Bi-Y biocomposites buried in soil. Polym Degrad Stab 91:3156-3162

10. Averous L, Boquillon N (2004) Biocomposites based on plasticized starch: thermal and mechanical behaviors. Carbohydr Polym 56:111-122

11. Soykeabkaew N, Supaphol P, Rujiravanit R (2004) Preparation and characterization of jute and flax-reinforced starch-based composite foams. Carbohydr Polym 58:53-63

12. Belay M, Sonkar AK, Nagarale RK, Verma V (2017) Synergistic strengthening of composite films by crosslinking graphene oxide reinforcement and poly(vinyl alcohol) with dicarboxylic acids. Polym Int 66:1737-1746

13. Guimaraes JL, Wypych F, Saul CK, Ramos LP, Satyanarayana KG (2010) Studies of the processing and characterization of corn starch and its composites with banana and sugarcane fibers from Brazil. Carbohydrate Polymers 80:130-138

14. Felix M, Perez-Puyara V, Romero A, Guerrero A (2017) Development of protein-based bioplastics modified with different additives. J Appl Polym Sci 134:Article number: 45430

15. Mlalila N, Hilonga A, Swai H, Devlieghere F, Ragaert P (2018) Antimicrobial packaging based on starch, poly(3hydroxybutyrate) and poly((lactic-co-glycolide) materials and application challenges. Trends in Food Science \& Technology 74:1-11

16. Kawashima, N., Yagi, T., Kojima, K (2019) How do bioplastics and fossil-based plastics play in an circular economy?, Macromolecular Materials and Engineering, 304(9):Article number: 19003383

17. Evans, J (2019) Feedstcks to make bioplastic packaging, biofuels \& Biorefining-biofrp, 13(6):1387-1387

18. Strnad, S., Oberhollenzer, Z., Sauperl, O., Kreze, T., Zemljic, L.F (2019) Modifying properties of feather keratin bioplastic films using kanjac glucomannan, Cellulose Chemistry and Technologies, 53(9-10):1017-1027

19. Siagian M, Tarigan P (2016) Production of Starch Based Bioplastic from Cassava Peel Reinforced with Microcrystalline Cellulose Avicel PH101 Using Sorbitol as Plasticizer. Journal of Physics 701:Article number: 012012

20. Rowe MD, Ersan E, Walters KB (2016) Bio-based plasticizer and thermoset polyesters: A green polymer chemistry approach. J Appl Polym Sci 133:43917 
21. Karthika P, Rajalakshmi N, Dhathathreyan KS (2012) Functionalized exfoliated graphene oxide as supercapacitor electrodes. Soft Nanoscience Letters 2:59-66

22. Makhtar NSM, Rodhi MNM, Musa M, Hamid KHK (2013) Thermal Behavior of Tacca leontopetaloides StarchBased Biopolymer. Int J Polym Sci Article Number:373854

23. Pereira AGB, Gollveia RF, de Carvalho GM, Rubira AF, Muniz EC (2009) Polymer blends based on PEO and starch: Miscibility and spherulite growth rate evaluated through DSC and optical microscopy. Materials Science \& Engineering C-Biomimetic and Supramolecular Systems 29:499-504

24. Sagnelli D, Hebelstrup KH, Leroy E, Rolland-Sabate A, Guilois S, Kirkensgaard JJK, Mortensen K, Lourdin D, Blennow A (2016) Plant-crafted starches for bioplastics production. Carbohydrate Polymers 152:398-408

25. Cortes-Trivino E, Martinez I (2018) Wheat gluten / montmorillonite biocomposites: Effect of pH on the mechanical properties and clay dispersion. eXPRESS Polymer Letters 12: 616-627 